\title{
RBR: Patrimônio Nosso e Nacional
}

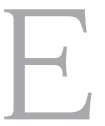

sta poderá não ser a melhor das gestões para a Revista Brasileira de Reumatologia (RBR). O objetivo é, nessas próximas doze edições que estarão sob a nossa responsabilidade, simplesmente fazer o melhor, o mais caprichado, o mais relevante. E desejar que a próxima gestão nos supere.

A diretoria executiva guarda inovações. Estamos criando novas assessorias de: Economia da Saúde; Estudos de Auto-Imunidade; Gestão e Demanda de Consultórios; Procedimentos; Relações com Convênios e Seguros de Saúde; e com Grupos de Pacientes. Além das tradicionais comissões, que devem continuar preocupando-se, cada vez mais, com a Ética Médica e a Defesa Profissional; o Ensino e a Educação Continuada; Epidemiologia; Título de Especialista; Recertificação; condições como a Artrite Reumatóide; Lúpus Eritematoso Sistêmico; Reumatologia Pediátrica; Osteoartrose; Osteoporose; Coluna Vertebral; Dor e Fibromialgia. Há novidades para necessidades antigas que serão contempladas agora com Comissões de: Atividade Física, Prevenção e Reabilitação; Doenças Endêmicas e Infecciosas; Vasculopatias; e Reumatologia Ocupacional e Relações Trabalhistas.

Nossas representações com organismos governamentais, instituições e entidades afins na área da saúde - nacionais e internacionais - serão expandidas, buscando aproximação também com outras especialidades e retomando nossa identificação com a comunidade luso-brasileira. E estaremos olhando um pouco mais para nós mesmos, na busca inédita, antes que tardia, pela Documentação e Registro Histórico da Sociedade Brasileira de Reumatologia (SBR).

Estamos iniciando com mudanças. E mudanças são fundamentais para o desenvolvimento. Não vai aí nenhum juízo de valores. O trabalho desenvolvido pelos últimos editores, Roger Abramino Levy e Laís Verderame Lage, na gestão Fernando de Souza Cavalcanti, dignificaram tanto a publicação quanto suas respectivas biografias. Em nome da SBR, presto aqui minha homenagem e, enquanto associado, meu agradecimento. Mas renovar é preciso, é saudável, é vital.

Para a função de editores da RBR convidamos dois representantes da nossa sociedade de inegável comprometimento com pesquisa e ensino, os colegas Francisco Airton Castro da Rocha, do Ceará, e Ricardo Machado Xavier, do Rio Grande do Sul. Capazes e com vivência na produção e na revisão de artigos e publicações. E, notem, também há uma representação geográfica nisso. Somos um país continental e hoje a abrangência de nossos valores chega às nossas fronteiras. Como co-editores, os professores Eloísa Silva Dutra de Oliveira Bonfá, Hilton Seda e João Carlos Tavares Brenol, e todo o Conselho Editorial serão chamados a contribuir com a tradição de seus nomes e o peso de suas experiências.

Equivoca-se quem entende que a globalização exige a uniformidade. O grande mérito do acesso à informação globalizada é a oportunidade de manter e demonstrar o que melhor nos caracteriza. A virtude de uma identidade própria. O que nos faz diferentes não nos torna melhores, faz-nos apenas diferentes. E únicos.

Nossa intenção é o acerto, o respeito à honra de representarmos uma especialidade também diferente, também única, de valores inquestionáveis.

A RBR continuará sendo o espelho de nossa produção científica, e todos os novos conceitos que estamos implantando terão nela também um veículo para questionamentos e visibilidade de resultados. A valorização da revista é dever de todos, que não se espere apenas publicando "lá fora". Seu futuro não interessa apenas a alguns, não pode ser a relevância de poucos. A indexação na MEDLINE é questão de tempo. Manteremos este compromisso. Autonomia científica, independência, porém patrimônio da SBR e da totalidade de seus associados. Uma tradição que completa em 2007 o seu primeiro cinqüentenário.

Um grande abraço a todos.

Fernando Neubarth

Presidente da Sociedade Brasileira de Reumatologia 2006-2008

Porto Alegre, primavera de 2006. 